\title{
Application of Realtime-PCR for Detection of 11 Urogenital Infections
}

\author{
Nguyen Thi Trang*, Nguyen Minh Thu, Nguyen Thi Quynh \\ Hanoi Medical University, UK
}

Submission: April 10, 2018; Published: May 01, 2018

*Corresponding author: Nguyen Thi Trang, Hanoi Medical University, UK, Email: trangnguyen@hmu.edu.vn

\begin{abstract}
Summary
Sexually transmitted diseases (STD) are a group of diseases that are common disease. They are not only affecting health, especially reproductive health but also affecting the socio - economy. Grace of the development of science and technology, now we have many modern methods for quick and accurate diagnosis STDs. A cross-sectional descriptive study, 300 men were consider genital infections. The samples were tested by Realtime PCR for identifing 11 microorganism. As a result, the rate infected microorganism is $72.9 \%$. The most common infection was Gardnerella vaginalis (45.7\%). The rates of mononucleosis and multiple infections were $49 \%$ and $51 \%$. Gardnerella vaginalis is the most common cause single infection and co-infection. Patients with age from 20 to 29 is the biggest group of men who are consider suffer from STD (42.7\%) and also is the biggest group infections STD (43.9\%).
\end{abstract}

Keywords: Surgical treatment; Renal cell carcinoma; Partial nephrectomy; Radical nephrectomy

Abbreviations: Sexually transmitted diseases; Infections; Realtime -PCR; STD; Urogenital

\section{Background}

Urogenital infections are a worldwide shared problem that represent the most common reason for a woman to decide to visit to gynaecologist or urologist [1]. A urinary tract infection (UTI) is an infection that affects part of the urinary tract. When it affects the lower urinary tract, it is known as a simple cystitis (a bladder infection) and when it affects the upper urinary tract, it is known as pyelonephritis (a kidney infection). The indigenous microbiota plays an important role in protecting the host from colonization of invading pathogens [1]. The most common pathogens are Chlamydia trachomatis, Neisseria gonorrhoeae, Gardnerella vaginalis...[2].

\section{Methods}

\section{Study design and study population}

We conducted a cross-sectional study over 300 patients who come to Hanoi Medical University Hospital in 2016.

\section{Realtime PCR protocol}

- $\quad$ The specimen is the secretion from the urethra. This specimen is then extracted with DNA by DNA - express kit (Lytech co.)

- $\quad$ Each optical tube of the kit has a mixture available. Take $10 \mu \mathrm{l}$ of the extracted DNA into each tube, then centrifuge and transfer to the realtime PCR machine.
- Choose FAM, HEX color respectively correspond to DNA, internal control.

- $\quad$ Set up the following program on realtime PCR machine.
i. $50{ }^{\circ} \mathrm{C} 1.5 \mathrm{~min}, 1$ cycle
ii. $95^{\circ} \mathrm{C} 15 \mathrm{~s}->60{ }^{\circ} \mathrm{C} 30 \mathrm{~s}, 40$ cycles

- Analyze the realtime PCR result in the computer.

Results

\section{Characteristics of study population}

The average age is $33.0 \pm 7.26$ years old, and the age group from 20 - 29 accounted for the highest proportion (Figure 1).

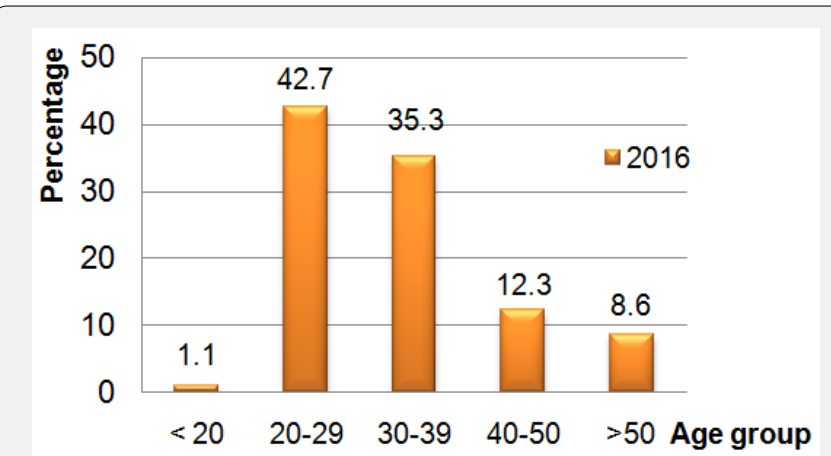

Figure 1: Percentage of patients by age group. 


\section{Percentage of study population with a positive bacterial STI}

The positive result is $72.9 \%$, which is higher than that of WHO [2]. This is because the prevalence of patients is higher than that of the population. In the group of patients with positive results, the most common age is also from 20 to 29 years. This age group is older than that of $\mathrm{N}$ Fournet et al. [3], due to differences in sexual habits between Vietnam and other countries [4] (Figure 2).

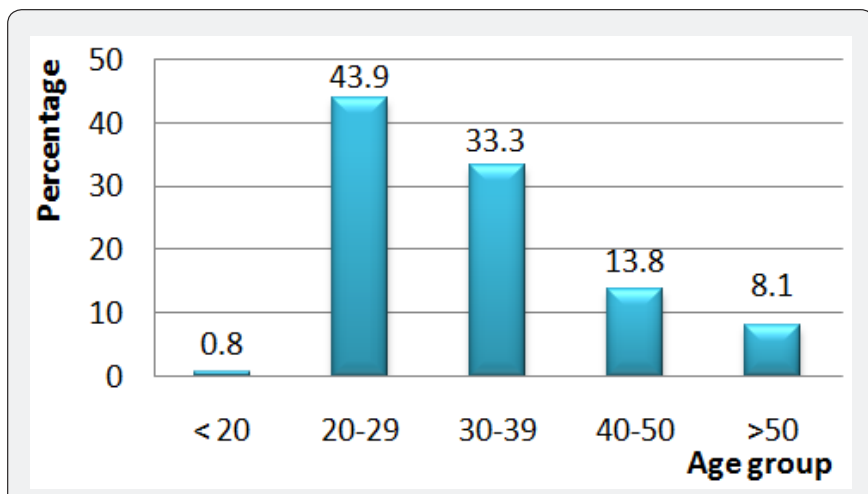

Figure 2: Percentage of UTIs by age group.

\section{Percentage of eleven STIs microorganism}

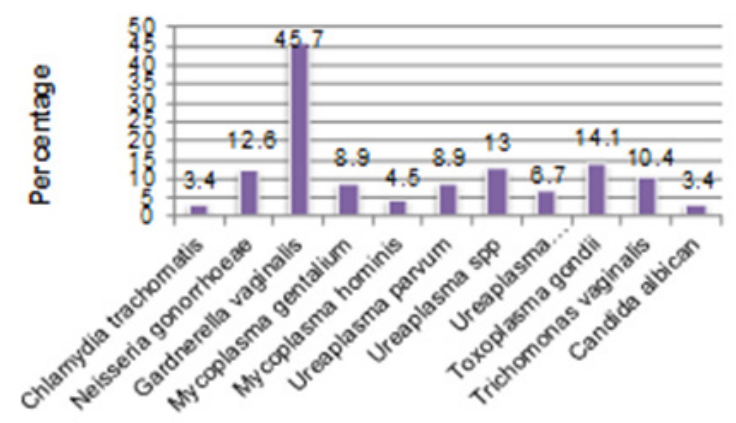

Figure 3: Percentage of microorganisms in UTIs.
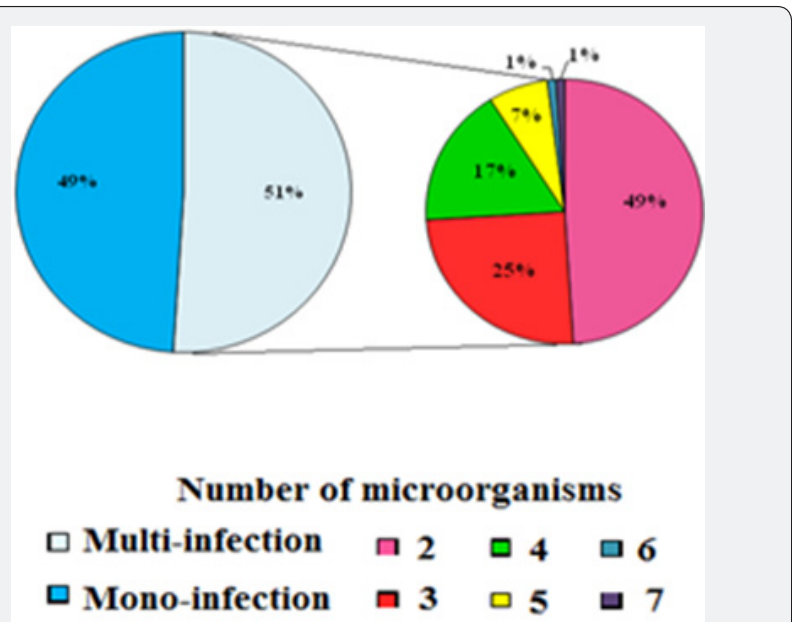

Figure 4: Percentage of mono-infection and multi-infection.
Over the study period, the most common species is $G$. vaginalis $(45.7 \%)$. But other study report a difference in results (C. trachomatis and N. gonorrhoeae) [3]. These differences could be explained by changes in study population characteristics over time and space. Another reason is the difference in test method [3] (Figure 3,4).

\section{Percentage of mono-infection and multi-infection}

The percentage between two groups was similar (49\% - 50\%). Patients with more microorganisms, the lower the percentage. At maximum, one patient had 7 microorganisms. Not only in the group of mono-infected but also in the group of multi-infected patients, the most common microorganisms is G. vaginalis. Mycoplasmas do not often appear alone but in combination with other microorganisms (Figure 5) (Table 1).

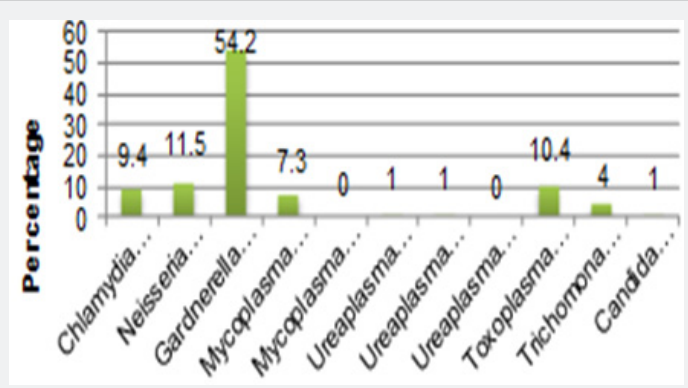

Figure 5: Percentage of microorganisms in group monoinfection.

Table 1: Popular group of microorganisms.

\begin{tabular}{|c|c|}
\hline Multi-infection & Percentage \\
\hline G. vaginalis - Mycoplasma & $36 \%$ \\
\hline G. vaginalis - C. trachomatis & $21.00 \%$ \\
\hline G. vaginalis - N. gonorrhoeae & $17.00 \%$ \\
\hline G. vaginalis - T. gondii & $17.00 \%$ \\
\hline T. gondii - Mycoplasma & $14.00 \%$ \\
\hline
\end{tabular}

\section{References}

1. Andreu A (2004) Lactobacillus as a probiotic for preventing urogenital infections. Rev Med Microbiol 15: 1-6.

2. WHO (2008) Global incidence and prevalence of selected curable sexually transmitted infections. Geneva, Switzerland.

3. Fournet N, Koedijk FDH, Van Leeuwen AD, Van Rooijen MS, Sande $\mathrm{MAB}$, et al. (2016) Young male sex workers are at high risk for sexually transmitted infections, a cross-sectional study from Dutch STI clinics, the Netherlands, 2006-2012. BioMed Central Infectious Diseases 10: 1188-1279.

4. Gutierrez JP, Bertozzi SM, Conde-Glez CJ, Sanchez-Aleman MA (2006) Risk behaviors of 15-21 year olds in Mexico lead to a high prevalence of sexually transmitted infections: results of a survey in disadvantaged urban areas. Public Health 11: 1186-1471. 
Your next submission with Juniper Publishers will reach you the below assets

- Quality Editorial service

- Swift Peer Review

- Reprints availability

- E-prints Service

- Manuscript Podcast for convenient understanding

- Global attainment for your research

- Manuscript accessibility in different formats

( Pdf, E-pub, Full Text, Audio)

- Unceasing customer service

Track the below URL for one-step submission https://juniperpublishers.com/online-submission.php 